\title{
Biogas production through Co-digestion of palm oil mill effluent with cow manure
}

\author{
*1Umar Hayatu Sidik, 2Firdausi Bin Razali, ${ }^{3}$ Sharifah Rafidah Wan Alwi, 4 Fadimtu Maigari \\ 1Department of Chemical Engineering, Federal Polytechnic, Mubi P.M.B. 35, Mubi Adamawa State. \\ 2Department of Bioprocess Engineering, Faculty of Chemical Engineering, Universiti Teknologi Malaysia, 81310, \\ UTM Johor Bahru, Johor Darul Ta'azim, Malaysia \\ 3Department of Chemical Engineering ,Faculty of Chemical Engineering, Universiti Teknologi Malaysia, 81310, UTM \\ Johor Bahru, Johor Darul Ta'azim, Malaysia \\ 4Department of Food Science and Technology, School of Engineering, Federal Polytechnic, Mubi P.M.B. 35 Mubi \\ Adamawa State. \\ [*Corresponding author: Email; hayatusiddiki@yahoo.com; 疋: +2348035989824]
}

\begin{abstract}
Palm oil mill effluent (POME) and cow manure (CM) are excellent substrates for biogas production. Biogas production potentials from POME and $\mathrm{CM}$ as a single substrate were extensively researched by many researchers. In this work, the biogas potentials from POME and CM as a single substrate as well as co-substrates were investigated. In addition, the effect of removal efficiencies of chemical oxygen demand (COD) and volatile solids (VS) towards biogas production and its methane content were also investigated. Batch anaerobic digesters used for the digestion were operated at ambient temperature $\left(28^{\circ} \mathrm{C}\right.$ to $34^{\circ} \mathrm{C}$ ) for 21 days. The digesters were operated at different mixing ratios. Maximum cumulative biogas yield and its methane content were obtained as $1875 \mathrm{ml}$ and $61.13 \%$, respectively in the mixture containing $70: 30$ (POME: CM). Co-digestion of 70\% POME + 30\% CM improved the removal efficiency up to $75 \%$ (COD) and $68 \%$ (VS). Biogas yield from digesters $D_{3}, D_{4}$ and $D_{5}$ were improved by $21 \%, 162 \%$ and $110 \% \mathrm{v} / \mathrm{v}$ using the codigestion as compared to the digestion of POME alone and $95 \%, 323 \%$ and $240 \% \mathrm{v} / \mathrm{v}$ as compared to the digestion of $\mathrm{CM}$ alone respectively. These results show that biogas and its methane content production can be enhanced efficiently through co-digestion process.

Keywords: Biogas, Methane, Anaerobic digestion, Co-digestion, POME and Cow manure.
\end{abstract}

\section{INTRODUCTION}

Depleting supply of fossil fuel which is non-renewable and the negative environmental impact associated with it have increased the interest in exploring for alternate source of cleaner energy such as biogas (energy from plant/animal origin) resources which are more sustainable, affordable and eco-friendly. Biogas is a gas made up of methane $\left(\mathrm{CH}_{4}\right)$, carbon dioxide $\left(\mathrm{CO}_{2}\right)$, and some trace of gases generated from biomass or organic materials under anaerobic conditions (Solomon and Lora, 2009). Biogas generation depends on several operating parameters namely total solid content, temperature, $\mathrm{pH}$, retention time, carbon to nitrogen ratio, mixing, chemical oxygen demand and volatile solids content which need proper monitoring and control to achieve maximum yield of biogas.

The anaerobic digestion process has been recognized as one of the most efficiently used method for conversion of biomass in an air tight environment to $\mathrm{CH}_{4}, \mathrm{CO}_{2}$ and other trace elements namely $\mathrm{H}_{2}, \mathrm{O}_{2}, \mathrm{~N}_{2}, \mathrm{CO}$ and $\mathrm{H}_{2} \mathrm{O}$ (Al-Masri, 2001). Conventionally, the anaerobic digestion process needs a large area to long retention time to enable microorganisms acclimating to the new environment before it can start to consume the substrates for their growth (Poh and Chong, 2009., Yang et al., 2004). This process involves four main stages namely hydrolysis, acidogenesis, acetogenesis and methanogenesis (Lam and Lee, 2011).

Anaerobic digestion of organic matter or biomass as a single substrate has been extensively researched and the investment returns from biogas production has been found (El-Masri and Zhang, 2010). This is because of the low biodegradability which leads to the low yield of biogas production from single digestion of the substrates. Amongst the approaches of enhancing the economics of anaerobic digesters for organic matter or biomass is to improve their biogas yield rate by co-digesting more than one organic matter together as long as such organic matter can augment the missing nutrients in the digesters (Mata-Alvarez et al., 2000).

Co-digestion would be the immediate breakdown of the homogenous mixture of several substrates. By tradition, anaerobic digestion involves only one substrate (particular purpose treatment e.g. manure to be digested for the purpose of energy production only). Nowadays, anaerobic digestion involves a diversity of substrate applied at the same time. 
In the present study, CM was used as a "carrier" substrate when co-digesting of POME with $\mathrm{CM}$ and has been identified as a new alternative method for improving the efficiency of the reactor as well as the biogas yield. Manure is suitable to be used as "carrier" substrate due to; its high buffering capacity that regulate the optimum $\mathrm{pH}$ in the reactor, and the high level of nutrient, micronutrients and other trace elements that enhance optimal bacteria growth (Tang et al., 2008).

Co-digestion of two or more substrates in a digester may enhance the anaerobic digestion process owing to improved carbon to nitrogen balance (Mshandete et al., 2004). In a related report by Mata-Alvarez et al. (2000) co-digestion of different substrates in the same anaerobic digester under mesophilic condition $\left(25^{\circ} \mathrm{C}\right)$ can improve the working power of the anaerobic digester positively and the augmented nutrients can enhance microbial activities which in turn increase biogas production as well as its methane composition. Misi and Forster (2001) also found that biogas production increases from 60 to $230 \mathrm{~L} / \mathrm{kg}$ VS by co-digesting of cow manure with $50 \%$ of molasses in a batch digester at $35^{\circ} \mathrm{C}$. Yadvika et al. (2007) found that anaerobic co-digesting of different substrates like manure (cattle swine) and fruit vegetable waste (FVW) under mesophilic condition gives a chance of treating waste, which cannot be treated separately.

The main objective of this research work was to measure the biogas production from co-digesting POME and cow manure as compared to digesting POME and cow manure separately by using anaerobic batch digester under ambient temperature.

\section{MATERIALS AND METHODS Feedstock Collection}

POME was collected from an anaerobic pond of palm oil mill FELDA Taib Andak factory situated at Kulai Johor, Malaysia. The sampling point was at least 100 $\mathrm{cm}$ deep of anaerobic pond. The POME was kept in a tightly closed 25 Liter water container. Cow manure was obtained from a slaughterhouse of a Veterinary Unit Public Health Division at Johor, Malaysia. All samples after collection were transported immediately to the biotransformation engineering research laboratory of Faculty of Chemical Engineering, Universiti Teknologi Malaysia and stored in a cool room of approximately $4^{\circ} \mathrm{C}$ to avoid microbial action until further use (Tang et al., 2008).

\section{Feedstock Preparation}

Stored POME and cow manure were taken out of the cool room. The feedstock was thawed until the temperature of the feedstock increased to a room temperature between $28^{\circ} \mathrm{C}$ to $34^{\circ} \mathrm{C}$. For cow manure, the feedstock was measured in its volume by using a measuring cylinder $(100 \mathrm{~mL} \pm 1 \mathrm{~mL})$. After being measured, cow manure was poured into a beaker $(500 \mathrm{~mL} \pm 50 \mathrm{~mL}$ ) to mix it with POME. POME was poured into beaker until the volume of the mixture reached a desired level. Before adding POME into the beaker, POME solution was stirred for 1 minute to homogenize it.

Later, the mixture of cow manure and POME was stirred again with a glass rod to improve their mixing. After that, mixing solution was transferred into anaerobic digester bottles by using a conical funnel.

\section{Operation Startup}

A total of five improvised batch digesters $\left(D_{1}, D_{2}, D_{3}\right.$, $D_{4}$ and $D_{5}$ ) each having a capacity of $1.5 \mathrm{~L}$ with $1.25 \mathrm{~L}$ working volume were used in this work. A $9 \mathrm{~mm}$ internal diameter of the $U$ - tubing and $1 / 4$ inch internal diameter valve were fixed on each cap of the batch digesters, silicon sealant was applied to ensure no air entrapment. The plastic gas bag was used for biogas collection. Prior to charging the digesters with the substrates, the U-tubing was charged with tape water at a marked level. The experiments were done under ambient temperature between $28^{\circ} \mathrm{C}$ and $34^{\circ} \mathrm{C}$. The first two digesters $\left(D_{1}\right.$ and $\left.D_{2}\right)$ were charged with POME and cow manure for mono-digestion, respectively. The last three digesters $\left(D_{3}, D_{4}\right.$, and $D_{5}$, were charged with the following mixture of POME and cow manure: $60 \%$ POME + 40\% cow manure, $70 \%$ POME $+30 \%$ cow manure then $80 \%$ POME $+20 \%$ cow manure for co-digestion respectively. The initial $\mathrm{pH}$ was recorded as neutral before the start of anaerobic digestion (AD). Nitrogen gas was purged through to expel oxygen from the digester and make it air tight in order to ensure anaerobic conditions in the headspace of anaerobic digesters (Hassan et al., 2004). The digesters were then attached to gas bag for gas collection. The gas generated was measured daily using the water displacement method by reading the volume of water displaced in the U-tubing which is equal to the volume of gas generated. Then the gas was collected by opening $1 / 4$ inch valve for the gas to flow into the biogas bag, and then thereafter the valve was closed until the next collection. Similarly mixing was done daily at the anaerobic digesters manually for one minute. The purpose of mixing in a digester was to enhance the digestion process by transferring heat throughout the digester and preventing formation of surface crust and scum (Sulaiman et al., 2009). 


\section{Analytical Methods}

The following parameters were measured before and after the experiment according to the standard methods (APHA, 2005). The parameters measured were; $\mathrm{pH}$, total suspended solids (TSS), total solids (TS), volatile solid (VS), chemical oxygen demand (COD), biochemical oxygen demand (BOD) and total organic carbon (TOC). The purpose of measuring the parameters mentioned above was to know their effects on the performance of anaerobic digestion process and biogas production.

\section{RESULTS AND DISCUSSION}

Characteristics of Substrates

The fresh POME and cow manure were analyzed with respect to volatile solids (VS), total solids (TS), total suspended solids (TSS), chemical oxygen demand (COD), biochemical oxygen demand (BOD) and total organic carbon (TOC) content as well as $\mathrm{pH}$. The summarized values of the parameters monitored for the substrates used in the experiment are shown in Table 1.

Table 1: Characteristics of the prepared substrates used in anaerobic digestion.

\begin{tabular}{|c|c|c|c|c|c|}
\hline Parameters & $100 \%$ POME & $100 \% \mathrm{CM}$ & $\begin{array}{l}60 \% \text { POME + 40\% } \\
\text { CM }\end{array}$ & $\begin{array}{l}70 \% \text { POME + 30\% } \\
\text { CM }\end{array}$ & $\begin{array}{l}80 \% \text { POME + } \\
20 \% \mathrm{CM}\end{array}$ \\
\hline $\mathrm{BOD}_{5}, \mathrm{mg} / \mathrm{L}$ & 377 & n.d & n.d & n.d & n.d \\
\hline COD, mg/L & 8,215 & 68,900 & 30,300 & 29,100 & 28,100 \\
\hline $\mathrm{TS}, \mathrm{mg} / \mathrm{L}$ & $1,722.82(4.1 \%)$ & $2,567.34(5.1 \%)$ & $2,060.63(4.8 \%)$ & $1,976.17(4.3 \%)$ & $1,891.73(4.2 \%)$ \\
\hline $\mathrm{TSS}, \mathrm{mg} / \mathrm{L}$ & 51.69 & 102.68 & 72.12 & 67.19 & 62.43 \\
\hline $\mathrm{pH}$ & 7.03 & 6.55 & 7.27 & 7.36 & 7.45 \\
\hline VS, mg/L & $1,260.60$ & 2013.6 & $1,561.8$ & $1,486.5$ & $1,411.2$ \\
\hline TOC & 136.23 & $4,027.2$ & $1,691.42$ & $1,303.46$ & 913.98 \\
\hline Water, \% & 96 & 88 & 89 & 90 & 92 \\
\hline
\end{tabular}

n.d = not determined

\section{Biogas Production}

The cumulative biogas production for the entire five digesters is shown in Figure 1. Digesters $D_{1}(100 \%$ POME), $\mathrm{D}_{4}(70 \% \mathrm{POME}+30 \% \mathrm{CM})$ and $\mathrm{D}_{5}(80 \%$ POME $+20 \% \mathrm{CM}$ ) started generating biogas at the first day of digestion while $\mathrm{D}_{2}(100 \% \mathrm{CM})$ and $\mathrm{D}_{3}$ (60\% POME + 40\% CM) did not. Water displacement method was used in measuring the biogas volume daily and the cumulative volume calculated as well. Biogas production was symbolized based on volume yield $(\mathrm{mL})$. The greater the amount displaced the higher the quantity of biogas generated. The biogas was collected at ambient temperature, between $28^{\circ} \mathrm{C}$ and $34^{\circ} \mathrm{C}$ at $1 \mathrm{~atm}$.

As can be seen in Figure1 digesters $D_{2}(100 \%$ CM) and $\mathrm{D}_{3}(60 \%$ POME $+40 \% \mathrm{CM})$ could not produce biogas until 15th and 10th days, respectively. Two factors which lead to delays in the biogas production. Firstly, due to the types of feeding that has been given to the cows which are mainly agricultural crops, such as maize stock. Roughly $90 \%$ of the dry weight of most plant materials is saved by means of cellulose, hemicellulose and lignin. The existence of lignin in lignocelluloses creates a protective barrier that stops plant cell destruction by fungi and bacteria for conversion to energy (biogas) unless of course pretreated (Angelidaki and Ellegaard, 2003). Many different pretreatment techniques modify the physical and chemical structure within the lignocellulosic biomass and improve hydrolysis rates. Pretreatment of cellulose facilitates hydrolysis for conversion to energy (biogas) (Angelidaki and Ahring, 1993).
Secondly, it might the result of volatile fatty acids (VFAs) accumulation due to the low biodegradability of cow manure, which resulted in partial inhibition in the digesters. When the volatile fatty acids (VFAs) were consumed, the partial inhibition will be overcomed and biogas production started. Despite the suspected accumulation of volatile fatty acids (VFAs), the $\mathrm{pH}$ value for digester $\mathrm{D}_{3}(60 \%$ POME + $40 \%$ CM) was maintained within the range of neutrality due to the cow manure buffering capacity as previously reported by Murto et al. (2004).

As biogas starts generating from digesters $D_{1}(100 \%$ $\mathrm{CM})$ and $\mathrm{D}_{3}(60 \%$ POME $+40 \% \mathrm{CM})$, the results show high biogas production for the first two days. This might be as a result of acclimatized methane forming bacteria activities as they overcome the protective barrier that prevents plant cell destruction by fungi and bacteria for conversion to energy (biogas) (Angelidaki and Ellegaard, 2003). Another possible explanation of this result is that most of the lignin, cellulose and hemicelluloses content of the substrate was degraded which make it accessible to the micro-organisms for conversion to biogas.

The biogas yield after 21 days was $717 \mathrm{~mL}, 443 \mathrm{~mL}$, $864 \mathrm{~mL} 1875 \mathrm{~mL}$ and $1504 \mathrm{~mL}$ from digesters $\mathrm{D}_{1}$ (100\% POME), D 2 (100\% CM), D 3 (60\% POME + $40 \% \mathrm{CM}), \mathrm{D}_{4}(70 \% \mathrm{POME}+30 \% \mathrm{CM})$ and $\mathrm{D}_{5}(80 \%$ POME $+20 \% \mathrm{CM}$ ) respectively. The biogas yields from co-digestion are significantly higher than that of mono-digestion of POME and cow manure alone. A significant percentage difference was found between 
co-digestion and mono-digestion. This study shows co-digestion in digesters $D_{3}, D_{4}$ and $D_{5}$ to be the best one and capable of improving the efficiency of biogas production by $95 \% 240 \%$ and $323 \%$ higher than digestion of cow manure alone $\left(D_{2}\right)$, and $21 \% 162 \%$ $110 \%$ higher than digestion of POME alone $\left(D_{1}\right)$ as shown in Table 2. This result supports the idea raised by Murto et al. (2004) who reported that co-digestion could improve biogas production by $50-200 \%$, depending on the operating condition and substrates used. Also, based on Ibrahim et al. (1984) anaerobic digestion of POME alone will affect its methanogenesis process as restricting steps. Methanogenesis is very important in anaerobic digestion because it is the terminal step of producing biogas. Low amount of methanogens will contribute to the slow rate of the biogas production.

In comparing the digesters fed with a mixture of POME and cow manure, the results indicate that the highest biogas production was achieved from digester $\mathrm{D}_{4}(70 \%$ POME $+30 \% \mathrm{CM})$. While the lowest biogas produced was achieved from the anaerobic digester $D_{3} \quad(60 \%$ POME $+40 \% \quad C M)$. The high variability in biogas production in the anaerobic digester $\mathrm{D}_{3}(40 \% \mathrm{CM}+60 \%$ POME) could be due to lower COD reduction, VS content and low amount of methanogens in cow manure. These findings are consistent with those of El-Mashad and Zhang, (2010) who reported that biogas production increase with an increase in COD removal and VS reduction, which can be well explained by the fact that the methanogenic consortium acclimated very well and consequently leads to the digestion of organic matter (COD) and volatile solid (VS) under anaerobic condition. This is an indication that the microorganisms in co-digester $\mathrm{D}_{4}$ (70\% POME + 30\% $\mathrm{CM}$ ) are more active in biogas production than other mixtures.

Removal efficiencies of COD, VS and methane production were calculated from the different amount in substrates and the results are given in Figure 2.

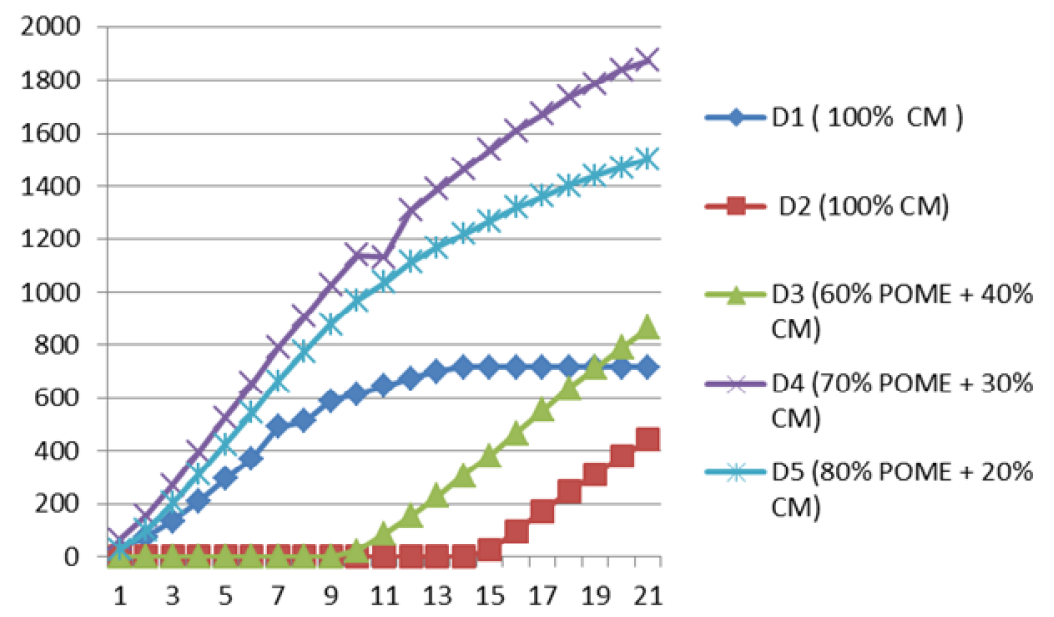

Figure 1: Cumulative Biogas Production after 21 days of digestion.

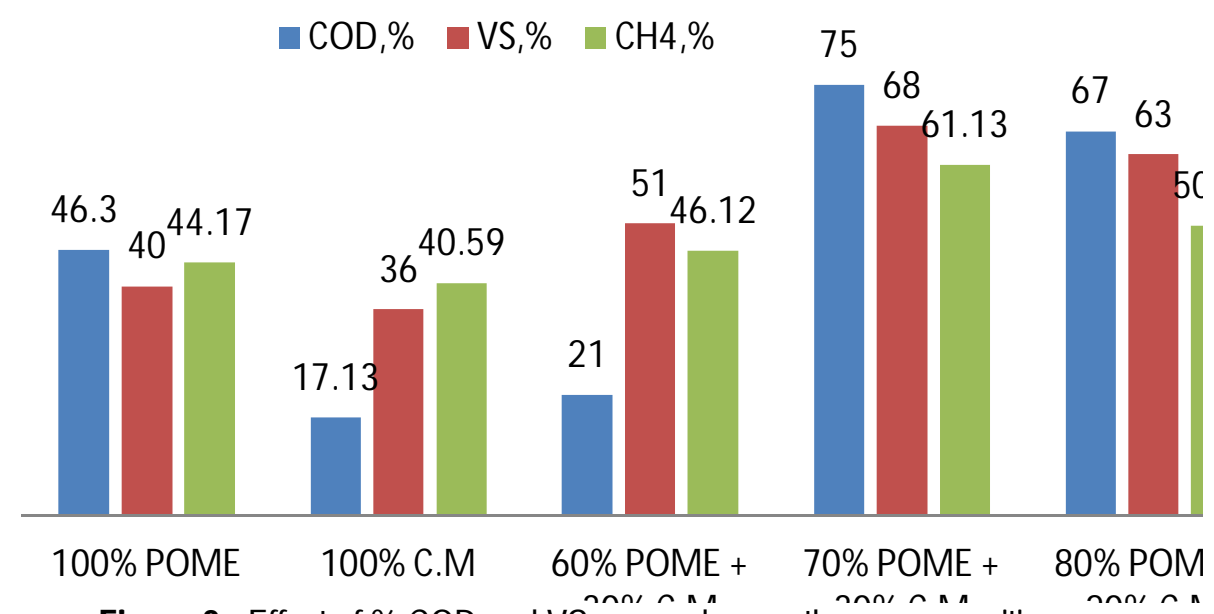

Figure 2: Effect of $\% \mathrm{COD}$ and $\mathrm{VS}$ removal on methane composition 
Digester $\mathrm{D}_{4}(70 \%$ POME $+30 \% \mathrm{CM})$ got the highest percentage of COD removal efficiency (67\%), hence higher percentage of methane content. While the lowest percentage of COD removal efficiency was achieved from the digester fed with cow manure alone, the COD removal efficiency was $46.3 \%$. Decreasing of COD shows that the anaerobic digestion is quite effective.

Figure 2, shows the effect of COD and \% VS removal efficiency on biogas production. It is really an indication that VS is a vital parameter for determining biodegradation which directly signifies the metabolic status of probably the most delicate microbe group within the anaerobic system. The VS reduction denotes the process stabilization. The maximum VS removal efficiency was achieved from the same digester fed with 70\% POME $+30 \% \mathrm{CM}$. Besides of VS and COD removal efficiency, there are other possible explanations in terms of $\mathrm{C}$ to $\mathrm{N}$ ratio. In the literature, the $\mathrm{C}$ to $\mathrm{N}$ ratio in the range of 25 and 30 continues to be recommended as optimal for anaerobic digestion, but there's been a contradiction using the ranges of 16 and 19 (Nyns, 1986) and 16.8 to 18 (Kivaisi and Mtila, 1998) been suggested as the ideal when lignin are taken into consideration. The digester $\mathrm{D}_{4}(70 \%$ POME $+30 \% \mathrm{CM}$ ) was found to be within the ideal range of $\mathrm{C}$ to $\mathrm{N}$ ratio for optimum biogas production and consistent with the findings of the above researchers.

\section{Biogas Quality}

Based on Figure 3, the result show the highest percentage of methane yield was achieved from anaerobic digester $\mathrm{D}_{4}(70 \% \mathrm{POME}+30 \% \mathrm{CM})$. The methane content was analyzed using GC-TCD (Agilent 6890 series GC System) with helium as a carrier gas with a flow rate of $30 \mathrm{~mL}$ per minute. The methane level achieved was $61.13 \%$. For other mixtures, it was $40.59 \%$ for ( $100 \% \mathrm{CM}$ ), $44.17 \%$ for (100\% POME), $46.12 \%$ for (60\% POME + 40\% CM) and $50.56 \%$ for (80\% POME $+20 \% \mathrm{CM}$ ). The remaining percentages were constituted by the following trace elements namely hydrogen $\left(\mathrm{H}_{2}\right)$, oxygen $\left(\mathrm{O}_{2}\right)$, nitrogen $\left(\mathrm{N}_{2}\right)$, carbon dioxide $(\mathrm{CO})$ and water $\left(\mathrm{H}_{2} \mathrm{O}\right)$. From this study, the mixing ratio of $70 \%$ POME $+30 \% \mathrm{CM}$ has been recognized as the optimum for biogas production as well as methane content. In this study, only $44.17 \%$ and $40.59 \%$ of methane has been produced from the anaerobic mono-digestion of POME and $\mathrm{CM}$ respectively. The potency of co-digestion is once more proven. Through co-digestion, the production level was elevated from $40.59 \%$ and $44.17 \%$ to much as 46.12 to $61.13 \%$ in term of methane composition.

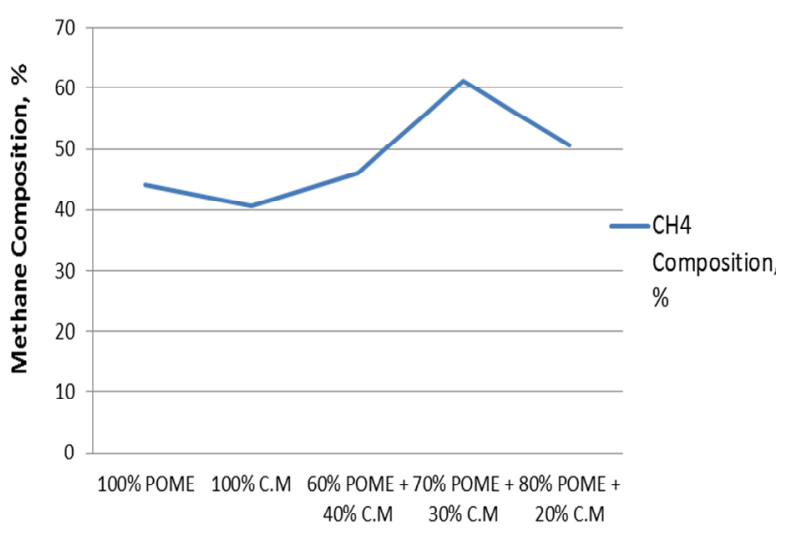

Substrates Composition, Vol\%

Figure 3: Final cumulative methane composition (\%) versus substrates composition (\%) after 21 day of digestion.

\section{CONCLUSION}

The present work, Shown that co-digestion of POME with $\mathrm{CM}$ shows promising results than digesting of POME and CM separately by anaerobic batch digester under ambient temperature conditions $\left(28^{\circ} \mathrm{C}\right.$ to $34^{\circ} \mathrm{C}$ ). The highest cumulative biogas production and its methane content were obtained as $1875 \mathrm{ml}$ and $61.13 \%$ respectively in the anaerobic digester containing mixture of $70 \%$ POME $+30 \% \mathrm{CM}$. Codigestion of $70 \%$ POME $+30 \% \mathrm{CM}$ improved the removal efficiency up to 75\% (COD) and 68\% (VS). Cumulative biogas yield from digesters $D_{3}, D_{4}$ and $D_{5}$ were significantly improved by $21 \%, 162 \%$ and $110 \%$ $\mathrm{v} / \mathrm{v}$ using the co-digestion compared to digestion of POME alone and 95\%, 323\% and 240\% v/v compared to digestion of $\mathrm{CM}$ alone respectively. This work shows that co-digestion (POME $+\mathrm{CM}$ ) was more effective than mono-digestion using batch anaerobic digester under ambient temperature.

\section{REFERENCES}

Al-Masri, M.R. (2001). Change in biogas production due to different ratios of some animal and agricultural wastes. Bioresources Technology, 77: $97-100$.

Angelidaki, I. and Ahring, B.K. (1993). Thermophilic digestion of livestock waste: the effect of ammonia. Applied Microbiology Biotechnology. 38: $560-564$.

Angelika, I. and Ellegaard, L. (2003). Co-digestion of manure and organic wastes in centralized biogas plant: status and future trend. Environmental and Resources, Technical University of Denmark. 
APHA (2005). Standard method for examination of water and wastewater. American Public Health Association, Washington, D. C..

Mata-Alvarez, J., Mace, S., and Liabres, P. (2000). Anaerobic digestion of organic solid wastes. An overview of research achievements and perspectives. Bio-resource Technology, 74(1): 3-16.

El-Mashad, H.M., and Zhang, R. (2010). Biogas production from Co-digestion of dairy manure and food waste. Bioresource Technology, 101: 4021-4028.

Hassan, M.A., Yacob, S. and Shirai, Y. (2004). Treatment of palm oil wastewaters. In: Wang, L.K., Hung, Y., Lo, H.H. and Yapijakis, C., editors. Handbook of industrial and hazardous wastes treatment. New York. Marcel Dekker, Inc. 719-36.

Ibrahim, A., Yeoh, B.G., Cheah, S.C., Ma, A.N., Ahmad, S., Chew, T.Y., Raj, R. and Wahid, M.J.A. (1984). Thermophilic anaerobic contact digestion of palm oil mill effluent. Water Science and Technology, 17: 155-165.

Kivaisi, A.K. and Mtila, M. (1998). Production of biogas from water hyacinth (Eichhornia crassipes) (Mart) (Solms) in a two stage bioreactor. World Journal of Microbiology Technology, 14: 125-131.

Lam, M.K., and Lee, K.T. (2011). Review and sustainable bio-energies production from Palm oil mill effluent (POME): Win-win strategies towards better Environmental protection. Biotechnology Advances, 29: 124-141.

Misi, S.N., and Forster, C.F. (2001). Batch codigestion of multi-component agro-waste. Bioresource Technology, 80(1): 19-28.

Mshandete, A., Kivaisi, A., and Rubindamayugi, M. (2004). Anaerobic batch co-digestion of sisal pulp and fish wastes. Bioresources Technology, 95(1): 19-24.
Murto, M., Bjo"rnsson, L., and Mattiasson, B. (2004). Impact of food industrial waste on anaerobic codigestion of sewage sludge and pig manure. Journal of Environmental Management, 70(2): 101-107.

Neves, L; Oliveira, R. and Alves, M.M. (2006). Enhancement of methane production from barley waste. Biomass and Bioenergy, 30(6): 599-603.

Nyns, E.J. (1986). Biomethanation processes. In: Schonborn, W. (editor). Microbial Degradations. Berlin. Wiley-VCH Weinheim. 207-267.

Poh, P.E., Chong, M.F. (2009). Development of anaerobic digestion methods for palm oil mill effluent (POME) treatment, Bioresources Technology, 100: 1-9.

Sulaiman, A.M.A., Sherai, Y., Abd-Aziz, S., Tabatabaei, M., Basu, Z., and Yacob, S. (2009). The effect of mixing on methane production in a semi- Commercial closed digester tank treating palm oil mill effluent. Australian Journal of Basic and Applied Science, 3(3): 1577-1583.

Solomon, K. R., and Lora, E.E.S. (2009). Estimate of the electric energy generating potential for Different sources of biogas in Brazil. Biomass and Bio energy, 33: 1101-1107.

Tang, G.L., Huang, J., Sun, Z.J., Tang, Q.Q., Yan, C.H., and Liu, G.Q. (2008). Biohydrogen production from cattle wastewater by Enriched Anaerobic Mixed consortia: Influence of fermentation Temperature and $\mathrm{pH}$. Journal of Bioscience, 106: 80-87.

Yadvika, S., Sreekrishnan, T. R., Sangeeta, K. and Vineet, R. (2004). Enhancement of biogas production from solid substrates using different techniques. Bioresource Technology, 95: 1-10.

Yang, Y., Tsukhara, K., Yagishita, T., Sawayama, S. (2004). Performance of a fixed-bed reactor packed with carbon felt during anaerobic digestion of cellulose. Bioresources Technology, 94 (2): 197-201. 